\author{
후두경피증 환자의 수술적 치료 2예 \\ 중앙대학교 의과대학 이비인후과교실 \\ 김경수 · 서강욱 · 백상흠 · 양훈식
}

\title{
Two Cases of Surgical Management of Pachyderma Laryngis
}

\author{
Kyung-Soo Kim, MD, Gang-Wook Seo, MD, Sang-Hum Bak, MD and Hoon-Shik Yang, MD \\ Department of Otorhinolaryngology-Head and Neck Surgery, Chung-Ang University, \\ College of Medicine, Seoul, Korea
}

\begin{abstract}
-ABSTRACT -
Laryngopharyngeal reflux (LPR) is somewhat different from classic gastroesophageal reflux disease in its patterns, mechanism, manifestations and so on. The chief complaints of LPR are known as sore throat, throat clearing, hoarseness and foreign body sensation, but heartburn is uncommon. Laryngeal manifestations of LPR are reported as globus pharyngeus, reflux laryngitis, pachyderma laryngis, contact granuloma or ulcer, laryngeal leukoplakia, Reinke's edema, posterior glottic stenosis, subglottic stenosis, laryngomalacia, vocal nodule or cyst, paroxysmal laryngospasm, malignancy, etc. Treatment for LPR includes changes of the diet pattern and lifestyle, and acid-suppresssing therapy (Medication and Antireflux surgery). Authors report two cases of effective management of pachyderma laryngis with huge interarytenoid mass associated with LPR which was refractory to medical treatment. Surgical excision of the lesion was effective for resolving symptoms and shortened treatment period. (J Clinical Otolaryngol 2004;15:294-298)
\end{abstract}

KEY WORDS : Laryngopharyngeal reflux · Pachyderma laryngis · Laryngoscopic surgery.

\author{
서 론 \\ 위식도역류질환은 위산이 식도로 역류하여, 가슴 쓰림, \\ 신트림의 임상 증 상을 나타내거나 식도의 형태학적 변화 \\ 를 초래하는 질환이다. \\ 역류성 식도염은 식도에 궤양이나 미란 등의 형태학적 \\ 변화가 있지만, 위식도역류질환은 가슴쓰림 등의 증세는 \\ 논문접수일 : 2004년 9월 24일 \\ 심사완료일 : 2004년 11월 23일 \\ 교신저자 : 김경수, 100- 272 서울 중구 필동 2가 82- 1 \\ 중앙대학교 의과대학 이비인후과교실 \\ 전화 : (02) 2260- 2175, 2176. 전송 : (02) 2264- 2174 \\ E- mail : cauent@ hananet.net
}

있어도 식도자체에 형태학적 변화가 없는 경우도 많으며, 인후두에도 다양한 변화를 일으키는 광범위한 질환으로 생각한다. 최근에는 가슴쓰림 등의 증세가 없이 위산이 인후두로 소량의 역류되어 이비인후과적인 인후두 증상 ( 인두이물감, 쉰목소리, 인두통) 과 호흡기 증상(만성 헛 기침, 만성 기침) 을 나타내는 질환을 인후두 위산역류증 (LPR, lary ngophary ngeal reflux)이라 부르고 있다. 인 후두 위산역류증은 이비인후과 신환중 상당히 많은 부 분을 차지하는 것으로 알려져 있다.

위산의 역류로 인해 초래되는 인두와 후두의 다양한 병 변 중에서도 특히 후두 경피증은 장기간의 약물치료를 하여도“ Elephant skin” 이라 하여 비가역적인 조직변 화로 인하여 후두의 증세가 호전되지 않는 경우가 많은 편이다. 
최근 저자들은 엄격한 식사 및 생활습관의 교정지도과 충분한 약물치료 ( 8 주) 를 했음에도 기침, 애성, 이물감 등 의 후두 증상이 지속되는 2 명의 후두경피증 환자에 대 해 후두미세수술로 치료를 시도하였기에 문헌고찰과 함 께 보고하는 바이다.

\section{증 례}

\section{증 례 1:}

58세 여자 환자로 1년 이상 지속되는 애성과 후두이 물감으로 간헐적으로 치료를 받아왔으나 호전이 없어 본원 외래에 내원하였다. 음주 및 흡연은 하지 않았으며, 수년전 위내시경을 통해 만성 위염 진단을 받은 바 있지 만 적극적인 치료는 받지 않았다. 위 내시경상 만성 표 재성 전정위염 이외에 식도에 궤양, 미란 등은 보이지 않았다. 후두내시경 소견상 피열연골사이 에서 발견되는 타원형의 커다란 종괴의 점막은 발적과 비후된 소견을
보였다(Fig. 1). 인후두 역류에 의한 후두의 병변인 후두 경피증 진단 하에 Cisapride와 $\mathrm{H}_{2}$ - blocker의 병합요법 을 8주간 시행했으나, 환자는 후두 이물감, 가피 섞인 객담, 애성은 지속되어 수술적인 치료를 시도하였다.

기관내 삽관튜브에 의한 후두 후부의 노출에 장애가 없 도록 시야확보를 위해 Jet ventilation을 이용한 마취를 하였다. 피열연골 사이의 비후된 병변을 미세 감자 및 미 세가위를 이용한 절제와 $\mathrm{CO}_{2}$ laser를 혼용하여 수술을 진행하였으며, 병변의 하부 절제 시에는 피열간근의 손상 과 출혈을 피하도록 주의를 하였으며, 양측 피열연골주 변 점막에 1 2 $\mathrm{mm}$ 의 여유를 두어 피열연골막의 노출 이나 손상을 피하였다. 병리학적 소견은 이상각화증, 림프 혈장세포의 침윤에 동반된 점막하 부종과 함께 경한 극 세포증이 관찰되었다 Fig. 2). 환자는 수술 후 약 3주간 의 추가적인 Cisapride와 proton pump inhibitor(PPI) 의 병합요법을 시행하였고, 현재( 술 후 2년) 특별한 증상 및 재발 없이 지내고 있다Fig. 3).
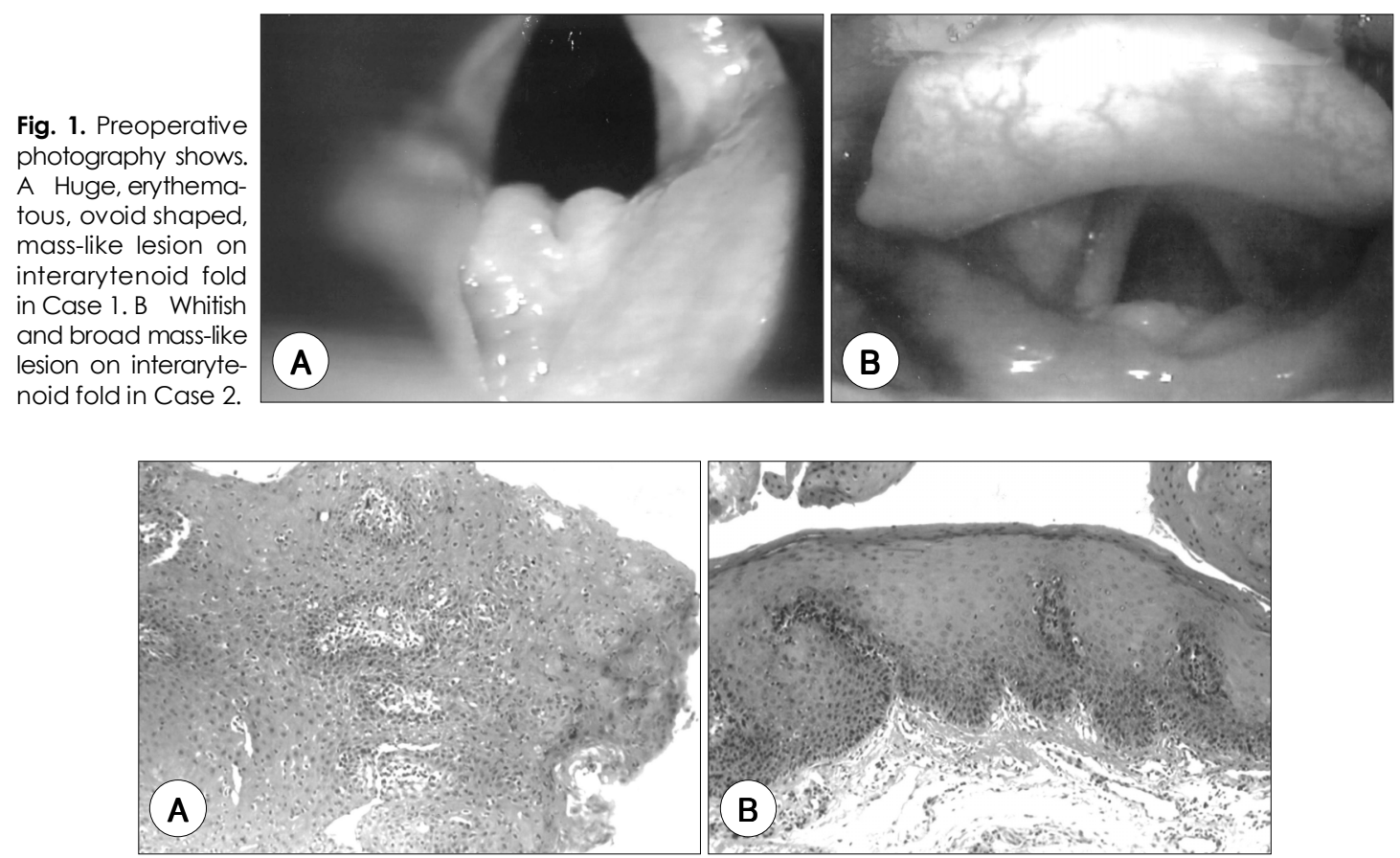

Fig. 2. Pathology. A : Mild acanthosis with parakeratosis, submucosal edema with lymphoplasmacytic infiltrations are noted in Case 1 ( Hematoxylin and Eosin stain : original magnification $\times 100$ ). B : Squamous epithelium with mild reactive change and lymphocytic infiltrations are noted in Case 2 (Hematoxylin and Eosin stain : original magnification $\times 100)$. 

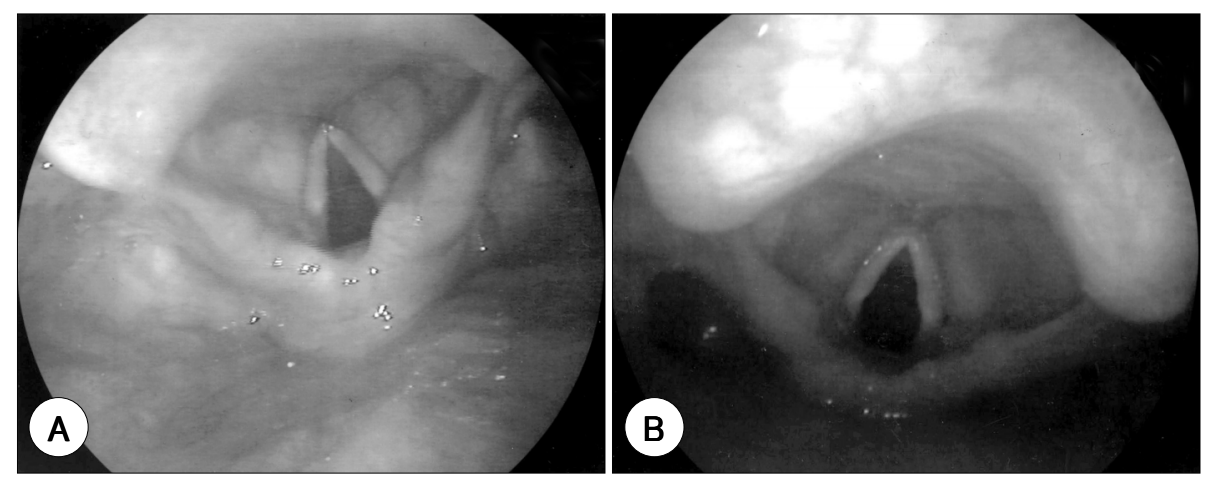

Fig. 3. Postoperative laryngoscopic view ( 4 weeks). A : Interarytenoid fold is mild edematous, but much improved in Case 1. B : Interarytenoid fold is nearly normalized in Case 2.

\section{증 례 2 :}

49세 여자 환자로 5년 전부터 지속되는 후두이물감으 로 간혹 개인병원에서 보존적 치료만 시행하였다. 내원 4 5개월 전부터는 후두이물감이 더욱 심해 져 내원하였 다. 음주 및 흡연 경력은 없었고, 2년 전에 십이지장 궤양 을 진단받았다. 이학적 소견상 피열연골사이에 백색의 종 괴가 보였고(Fig. 1), 기타 부위의 이상소견은 보이지 않 아 후두 경피증 진단 하에 $\mathrm{H}_{2}$ - blocker와 Cisapride의 병합요법을 8주간 시행하였으나, 증상호전 보이지 않아 수술적 인 치료를 권유하였다.

기관내 삽관튜브에 의한 후두 후부의 노출에 장애가 없 도록 시야확보를 위해 Jet- Ventilation을 이용한 마취 를 하였다. 피열연골사이의 비후된 병변을 증례 1 과 같은 수술 방법으로 제거하였다. 병리학적 소견은 림프구의 침윤과 편평상피세포의 염증반응에 따른 변화를 보이는 것 이외의 특별한 소견은 관찰되지 않았다F Fig. 2). 환 자는 수술 후 2 주간의 추가적인 수술 전과 동일한 약물 치료를 시행한 이후에 후두 이물감은 소실되어서, 현재 (술 후 1년) 식사 및 생활 습관의 개선을 통해 재발 등의 다른 문제없이 외래 통해 추적 관찰 중이다Fig. 3).

\section{고 찰}

인두 신경증, 역류성 식도염, 후두 경피증, 라인케씨 부 종, 후방 성문 협착증, 성문하 후두협착증, 후두연화증, 성 대결절과 낭종, 발작적 후두경련, 그리고 후두악성종양 등 다양한 질환이 위산의 역류와 직접 혹은 간접적으로 연관이 있으나, ${ }^{1,}$ 위식도 역류질환과 증상, 징후와 발생기
전에 차이가 있기 때문에 인후두 역류증의 진단이 덜 되 는 실정이다. ${ }^{2}$

인후두 위산역류증 환자는 애성 등의 발성장애, 기침, 이 물감, 인후통 등의 증상을 주로 호소한다. Noordzij 등ㄱ 에 따르면 이러한 증상 중 가장 인후두 위산역류증상과 연 관이 높은 증상은 만성적인 헛기침(Throat clearing) 이 라고 한다. 또한 후두 경피증 환자의 주증상도 인후두 위 산역류증과 비슷하여 헛기침, 애성, 건조감, 이물감이라 고 한다. ${ }^{3)}$

후두 경피증 뿐만 아니라 인후두 위산역류증과 연관된 질환의 진단은 환자들이 호소하는 증상과 인후두의 내시 경 검사가 기본적이고, ${ }^{4)}$ 이동형 24시간 이중탐침 $\mathrm{pH}$ 검 사 ambulatory 24- hr double probe pH monitoring) 가 확진을 위한 가장 좋은 방법으로 되어 있으나,5) 저자 들은 환자의 증상과 내시경적 소견이 전형적인 후두경 피증이라 생각되어 24시간 이중탐침 $\mathrm{pH}$ 검사는 시행하 지 않았다. 후두 내시경적 소견은 매우 다양하여 진성대의 경미한 부종에서부터 호흡기의 전반적인 부종과 협착에 이르기까지 다양한 변화를 보인다.이러한 후두의 소견은 인후두 위산역류정도와 연관성이 없다. ${ }^{3}$

Peter 등에에 의하면 인후두 위산역류 환자의 후두 내시경을 이용한 검사에서 후두의 임상적 병의 정도를 다음의 8 가지로 분류하였다.
1) Pseudosulcus vocalis
2) 후두실폐쇄(Ventricular obliteration)
3) 발적/충혈(Ery thema/hy peremia)
4) 성대부종(Vocal cord edema)
5) 미만성 성대부종( Diffuse lary ngeal edema) 
6) 후두 후부비대(Posterior commissure hypertrophy)

7) 육아종(Granuloma/Granulation)

8) 후두내 농축점액(Thick endolary ngeal mucus) 이중에서 미만성의 후두부종을 다소 주관적이기는 하 지만 Endolaryngeal airway /whole lary $\mathrm{nx}$ 의 비율에 따라 그 정도를 Grade 1 4까지 분류하였는데 후두 경피 증은 Grade 3에 해당되며, 후두의" Elephant Skin”이 라는 표현을 사용하였다.

후두 경피증의 병리학적 소견은 극세포증, 각화증, 착 각화증에 의해 상피의 비후가 오고, 상피의 성숙은 정상 이고 각화이상은 없다. 상피하 조직의 염증은 드물고 악 성변화는 없는것으로 되어 있으나, 후두 경피증의 특징적 인 병리학적 소견에 대한 참고문헌은 거의 없다. 하지만 Close 등ㄱ에에 의하면 인후두 위산역류의 장기간 추적결 과 관찰되는 합병증으로 만성 기관지 폐질환, 반복적인 폐렴, 만성 기침, 만성적인 또는 반복적인 후두염, 그리고 구강내 질환을 보고하였고, 또한 후두악성 종양의 발생 과 관련된 위험인자로 보고하였다. 이 때문에 Bough 등ㄱ 은 인후두 위산역류증은 위식도 역류증보다 좀 더 적극적 이고, 장기적인 치료가 필요하다고 보고하였다.

인후두 위산역류증의 치료로는 크게 생활습관의 변화, 산분비 억제제투여, 수술적치료 등이 있다. 인후두 위산역 류증의 치료 방법의 선택은 증상과 심한 정도 그리고, 치 료에 대한 환자의 반응에 따라 결정되는데, 경한 증상일 때는 제산제의 사용만을, 중등도의 증상에서는 산분비 억 제제 $\left(\mathrm{H}_{2}\right.$ - blocker $)$ 와 운동 항진제인 Cisapride의 병합 요법을 권하였으며, 아주 심한 증상에서는 Proton pump inhibitor(PPI)와 cisapride의 병합 요법을 이용하거나 수술이 필요한 경우에는 위저부추벽 성형술이 필요하다 고 제안하였다. ${ }^{8)}$ 그러나 최근의 기본적인 치료 경향으로 는 생활습관과 식습관의 변화와 함께 $\mathrm{H}_{2}$ - blocker, PPI 를 병용하는 약물요법이 선호되고 있고, 이러한 치료 방 법의 선택으로 인후두 위산역류증 환자의 $60 ~ 90 \%$ 가 증상이 호전되었음을 보고하고 있다.9- ${ }^{11)}$

인후두 위산역류증 환자의 수술적 치료에 관한 논문은 아직까지 국내에서보고된 바가 없으며, 외국논문에서도 드문 편이다. 이중 인후두 역류증과 관련된 후두의 질환 으로 수술적인 방법이 선택되는 것으로 보고되는 것은
성대돌기육아종이 주종을 이루고 있는데, Jaroma 등리 은 성대돌기육아종 환자에서 기도폐쇄, 발성곤란, 조직학 적 진단이 필요한 경우에 실시한다고 보고 하였다.

하지만 인후두 위산역류증과 연관된 후두 경피증에 대 한 치료방법으로 내과적인 치료 방법이외에는 국내 및 외국 논문에 보고된 바가 없다. 후두 경피증 등의 중등도 이상의 인후두 위산역류증의 경우는 이미 조직학적인 변 화가 비가역적으로 발생한 경우이고, 이에 의한 Throat clearance의 증가, 기침과 고형성분의 기관지 분비물 배 출, 인두 이물감, 목소리변화는 오랜 기간 환자가 고통스 러워하는 증상들이다.

이에 본 저자들은 결과적으로 조직학적 소견은 가역 적인 병변이었으나, 주된 치료방법인 내과적인 8주간의 약물치료에도 증상 호전이 전혀없고, 후두 내시경 상 이 미 거대한 종괴형성이 되어 있고, 조직검사가 필요할 정 도로 종괴가 커서 수술적 제거가 반드시 필요할 것으로 판단되여 수술을 시행 하였고, 그 결과 증상호전 및 약물 치료 기간이 현저히 단축되었다.

저자들은 모든 후두경피증 환자에서 후두 미세 현미경 수술을 적용할 수는 없으나, 첫째는 충분한 내과적 치료 에도 불구하고 환자의 증상 호전이 전혀 없는 경우, 둘째 는 후두 내시경 상 이미 조직학적인 변화가 의심되는 경 우, 셋째는 종괴의 크기가 너무 커서 후두 악성 종양 등 의 다른 질환과의 감별이 필요한 경우에는 수술적인 치 료방법을 선택해 보는 것도 환자의 증상 호전 및 치료 기 간의 단축을 유도할 수 있다고 생각한다.

중심 단어 : 인후두 위산역류증 후두경피증 후두 미세 현미경 수술.

\section{REFERENCES}

1) Koufman JA. The otolaryngologic manifestations of gastroesophageal reflux disease. A clinical investigation of 225 patients using ambulatory 24-hour pH monitoring and an experimental investigation of the role of acid and pepsin in the development of laryngeal injury. Laryngoscope 1991;101:1-65.

2) Koufman JA. Laryngopharyngeal reflux is different from classic gastroesophageal reflux disease. Ear Nose Throat J 2002;81:7-9.

3) Noordzij JP, Khidr A, Desper E, Meek RB, Reibel JF, Levine PA. Correlation of $p H$ probe-measured laryngopharyngeal reflux with symptoms and signs of reflux laryngitis. Laryng- 
scope 2002;112:2192-5.

4) Koufman J, Sataloff RT, Toohill R. Laryngopharyngeal reflux: Consensus Report. J Voice 1996;10:215-6.

5) Close LG. Laryngopharyngeal manifestations of reflux: diagnosis and therapy. Eur J Gastroenterol Hepatol 2002; 14:S23-27.

6) Peter C. Belafsky PC, Postma GN, Amin MR, Koufman JA Symptoms and findings of laryngopharyngeal reflux. Ear Nose Throat J 2002;81:10-3.

7) Bough ID Jr, Sataloff RT, Castell DO. Gastroesophageal reflux laryngitis resistant to omeprazole therapy. $J$ Voice 1995;9:205-11

8) Koufmann JA. Gastroeophageal reflux and voice disorders.
In: Rubin, editor. Diagnosis and treatment of voice disorders. 1st ed. New York, Tokyo: Igaku-Shoin; 1995. p.161-75.

9) Hanson DG, Kamel PL, Kahrilas PJ. Outcomes of antireflux therapy for the treatment of chronic laryngitis. Ann Otol Rhinol Laryngol 1995; 104:550-5.

10) Metz DC, Childs ML, Ruiz C, Weinstein GS. Pilot study of the oral omeprazole test for reflux laryngitis. Otolaryngol Head \& Neck Surg 1997;116:41-6.

11) Rival R, Wong R, Mendelsohn M. Role of gastroesophageal reflux disease in patients with cervical symptoms. Otolaryngol Head \& Neck Surg 1995;113:364-9.

12) Jaroma M, Pakarinen L, Nuutinen J. Treatment of vocal cord granuloma. Acta Otolaryngol 1989;107:296-9. 